is still nearly the lingua scientifica, scientists must learn more languages, not only Russian, and that consideration should be given to the fact that, whereas in the U.S.S.R. scientific documentation is a State matter, in Great Britain it is dependent on industry and the business houses.

The success of the Congress was borne out by the attendance of more than three hundred delegates, about one-third of whom were from overseas. There was a full programme of excellent social events.

\section{SCIENCE MASTERS' ASSOCIATION}

\section{ANNUAL MEETING IN LONDON}

$\mathrm{A}$ BOUT a thousand science masters met in London at the Royal College of Science, South Kensington, for four days in the week between Christmas and New Year, the occasion being the annual meeting of the Science Masters' Association. Residential accommodation was provided, as usual, at Queen Elizabeth College, Campden Hill Road, which also entertained visitors in its laboratories on two evenings. Teachers were present from the Netherlands, Natal, Pakistan and India, and Unesco sent an observer.

For his presidential address, Sir Edward Salisbury, director of the Royal Botanic Gardens, Kew, chose the theme "Science and Education". He began by saying that his life had been spent in the study of ecology, from varied approaches, and that this might have been no bad preparation for suggesting ways in which the disciplines derived from different studies might be integrated. The greatest danger to real education, he said, is to mistake the provision of information for the imparting of knowledge; it is much easier to acquire strands of information than to weave them into a harmonious whole. Science teaching should therefore stress the structural unity of all knowledge. He recalled that the test he applied when he taught botany students was to ask whether their studies made a walk in the country more interesting; if not, they should try some other subject. He thought that a similar test might well be applied to all learning: Does it make life richer and more colourful ?

A marriage of science and the humanities is essential to the success of the civilization of the future, and in order to achieve this, Sir Edward thought that the scientist should write good English and that the humanist should take the trouble to understand him. $\mathrm{He}$ deplored the passing of the general use of the Bible, which had set a standard of English expression, not less valuable because often unconsciously acquired. Science, he went on, should set itself not only to amass facts but also to create good citizens ; but it should beware of exaggerating the importance of what is measurable, since some most significant things are not to be measured. Good science teaching should avoid the pitfalls of doctrinaire politics and ensure a sense of proportion and a balanced judgment, though these are not qualities gaining publicity in the more sensational newspapers. Sir Edward also said that the need in schools is to stress the fact that to live is more than livelihood, and that only by habitual zest in one's working-hours can one ensure the zestful enjoyment of one's leisure. "To go slow in the one is the surest way of finding that time hangs heavy in the other". On the science teaching in schools there rests a great responsibility, but there are also the potentialities of a great achievement.

Each morning of the meeting began with two simultaneous lectures, those on the first morning being by Prof. L. J. Audus (Bedford College, London) on the attempts made during the Second World War by biologists in Japanese prisoner-of-war camps to stem the onset of deficiency diseases; and by Dr. C. C. Butler (Imperial Gollege of Science and Technology, London) on the story of cosmic rays. The lectures on the second morning were by Prof. R. M. Barrer (Department of Physical Chemistry, Imperial College, London) on crystals as molecular sieves, and by Prof. F. A. Vick (Department of Physics, University College of North Staffordshire) on electrical aspects of contacts between solids. On the last morning lectures were given by Prof. R. J. Harrison (London Hospital Medical College) on recent research on whales and seals, illustrated by a film, and by Mr. H. W. Thorp (Department of Chemical Engineering, University College, London) on chemical engineering, which was also illustrated by films; a third lecture, later on the same morning, was by Mr. A. B. Soper (Cable and Wireless, Ltd.) on Commonwealth telecommunications.

Some of the most popular functions were the demonstrations and discussions. A lecture-demonstration on experiments with radioactive isotopes suitable for schools had to be repeated four times, the first version being attended by more than two hundred, who somehow got into a lecture theatre built for seventy; it was given by M. C. Nokes (Harrow), J. S. Strettan (Raynes Park Grammar School), T. A. H. Peacocke (St. John's School, Leatherhead), G. E. Perry (Kettering Grammar School) and W. G. Rhodes (Firth Park Grammar School, Sheffield). Another most popular demonstration was by K. A. Murch (Chichester High School for Boys) on ciné and ciné-micrography in the teaching of natural history.

A very valuable and provocative discussion, under the chairmanship of Mr. F. W. Kaye, was that on science in secondary modern schools-progress and prospects; it was initiated by A. E. J. Trinder (Alexandra Secondary Modern School, Bromley), and many members took part. The discussion on the last morning was on first-year failures in the universities, and for this Dr. H. F. Boulind (general secretary of the Association) was in the chair. It was introduced by Dr. E. R. Roberts (Department of Inorganic Chemistry, Imperial College) and by Prof. F. A. Vick. Representatives of the various colleges of the University of London had been invited to be present, and several spoke. It was generally agreed that the schools need to concentrate on trying to make pupils think, rather than on giving instruction for examinations, but how this is to be done was not so apparent. It is hoped that a tape-recording of the discussion may later be put into print. The third discussion was one by the Science and Religion Group of the Association, which was welcomed by the Rev. D. W. Cleverley Ford, vicar of Holy Trinity Church, Prince Consort Road, London, S.W.7. Many members spoke, and the proceedings ended with a gratifying increase in the numbers of the Group.

Evening functions included a lecture in the Courtauld Hall of Queen Elizabeth College by Mr. T. D. Bourdillon, on "Everest, 1953". Mr. Bourdillon, who was a member of the successful 1953 Everest Expedition, showed and explained the oxygen 
equipment and other gear which he used; his lecture was illustrated by most beautiful slides.

As usual, a main feature of the meeting was provided by the exhibitions of apparatus and books by manufacturers and publishers; these, together with the exhibition of teaching apparatus devised by members, were bigger than ever before, and strained the accommodation of the Royal College of Science to the utmost. The Home Office contributed a display of apparatus used in Givil Defence work by technical reconnaissance officers, and also lent a control set and 'walkie-talkies' so that officers of the Association could maintain contact with the secretary's office from any part of the College. Some sixteen firms were visited by members during the afternoons, as also were the High Pressure Laboratories of the Chemical Engineering Department at the Imperial College. In addition, on each afternoon scientific films were shown, some of which wero introduced by Dr. J. A. Harrison (Educational Foundation for Visual Aids).

The meeting created a record for attendance, and the Association must count itself as singularly fortunate in this year's president, Sir Edward Salisbury, who insisted on sharing in all the activities; his zest showed that he was not content with precept in his address, but followed it with action during the meeting.

\section{FARMING HISTORY IN GREAT BRITAIN}

$\mathrm{F}$ ARMERS, industrialists and scholars from all over Great Britain attended a joint meeting of the British Agricultural History Society and the Association of Agriculture, which was held in the University of London on December 3. Sir James Scott Watson, president of the History Society, took the chair, and three papers were read, one in the morning and two in the afternoon. This event, which is one of the two annual meetings convened by the Agricultural History Society, is usually open to nonmembers on payment of the conference fee.

The morning paper, read by Dr. H. Harnshaw Thomas, prosident of the History of Science Society, dealt with the life and writings of Richard Bradley, F.R.S., who lived in the early years of the eighteenth century. The paper gave much food for thought, for Bradley came very close to some of the most modern scientific discoveries. By a series of experiments he found that variegated leaf colours could be induced in healthy plants by grafting scions of discoloured plants. The variegation, which is really a virus disease, was, he found, transmitted through tho circulation of the sap. Similarly, he was able to produce the breaking of tulip bulbs, which was forgotten or neglected until Sir Daniel Hall, all unknowingly, so it is thought, repeated Bradley's experimental work on modern lines. Besides his achievements in pure science, Bradley was a severely practical man. 'Through correspondents and personal observation he collected and recorded a great mass of information about the farm practice of his day. As Dr. Hamshaw Thomas said, a complete description of English farming methods of the early eighteenth century can be compiled from his work. Until the present day, Bradley has been regarded as somewhat of a charlatan, but Dr. Hamshaw Thomas's work has done much to retrieve his reputation.
After lunch the first paper was by Prof. Cyril Tyler, of the University of Reading, who dealt with the historical development of feeding standards for livestock, a subject that must be very close to the hearts of farmers in these times. Prof. Tyler ranged over the ages from classical times until the present day, describing the theories of the ancients and the slow progress that was made in gaining real knowledge of the subject until von Thaer's work in the early nineteenth century. It was unfortunate that von Thaer chose such a variable as good hay for his basic unit, but his work pointed the way. Many German and British chemists followed in his steps and, with slowly increasing knowledge, have to-day been able to lay down simple and practical rules for tho breeder, dairy farmer and meat producer alike. It is a fascinating story and demonstrates, if that is necessary, that the findings of science are of universal application.

The third paper was rather more recondite and dealt with pollen analysis and its bearing on agricultural history, being given by Mr. J. W. Franks, of the Department of Botany, University College, Leicester. Mr. Franks demonstrated how what happened in districts now covered with peat or fen can be discovered by cutting down through the layers. The depth of the layers and other indications show how long they have taken to accumulate. In these layers of peat the pollen of the various flora that flourished is embedded and preserved, and by carefully collecting this pollen, identifying it and counting it, the flora of that particular age can be deduced. If man was living in the place when the pollen was deposited, his activities in growing cereal or other crops, or the effect of grazing animals, will be shown by the different pollens recovered.

All three papers dealt with subjects that were well worth while, and the conference was a great success. Those interested in this field should write to the Honorary Secretary, British Agricultural History Socjety, Mr. J. W. Y. Higgs, at the Museum of English Rural Life, 7 Shinfield Road, Reading.

\section{GOVERNMENT RESPONSIBILITY IN INDUSTRIAL RESEARCH}

$T$

HE extent and character of the rosponsibility taken by governments for research varies enormously. In the scientifically more advanced countries, the government attitude ranges from the benevolence combined with restricted actual participation to be found in Germany and the United States to the complete control of science exercised in the U.S.S.R. Even within the British Commonwealth, where there is a common tradition of government, the countries have developed different ways of reaching the level of research activity essential in a rnodern State. Some of the differences and the reasons for them were brought out in a discussion on "Government Responsibility in Industrial Research" held at the Society for Visiting Scientists on December 6 under the chairmanship of Sir Henry Tizard. The principal speakers were Dr. E. W. R. Steacie, president of the National Research Council of Canada, and Dr. B. K. Blount, deputy secretary of the Department of Scientific and Industrial Research, and there were contributions from a number of Commonwealth countries and the United States. 